\title{
Research Determinant Factors of Overweight and Obesity in Children 11-15 Years Old in Tirana Schools
}

\author{
Elida PEKA ${ }^{1}$, Dr Enver ROSHI ${ }^{2}$, Jolanda ZOGA ${ }^{3}$, Englantina ZOGA ${ }^{4}$, Fatime ZOGA ${ }^{5}$ \\ ${ }^{1}$ Lecturer Faculty of Technical Medical Sciences, Medical University of Tirana \\ ${ }^{2}$ Professor, Dean Faculty of Public Health, Tirana \\ ${ }^{3}$ Teknicient Laboratory, the Service of Genetics, University Hospital Center \\ ${ }^{4}$ Specialist, I Relations with the Public Sector, Tirana \\ ${ }^{5}$ Specialist, I Relations with the Public Sector, Tirana
}

\begin{abstract}
The aim: Assessment of nutritional status of a group of children aged 11-13-15 years old district of Tirana (overweight and obesity). The objective of the study: Evaluation of the prevalence of obesity, overweight, children in developing age 11-13-15 years; Assessment of children's body image by BMI indicator that. Population study: The study included a total of 520 children distributed in 26 schools of which 18 in the city and 8 in the village. Survey Methodology: Transversal (cross- sectional), I prospectiv two component type; Descriptive, this component refers to description / assessment of the prevalence and distribution of risk factors and analytical in order to assess the connection (association) of food items with demographic, socio-economic and lifestyle. The sampling method used is stratified sampling in clusters, in accordance with the size of the population, recommended by WHO / UNICEF. The selection method according to residence (urban / rural) and type of school was based on the size of the target population. Type of school (public / private) was not considered in the selection layer, but a variable in the analysis, because the layer "rural", not the type of school represented "Private". Results: Our data highlighted that $15.2 \%$ of children were overweight and $3.1 \%$ were obese, and according to age groups surveyed for children 11 years old showed $12.5 \%$ were overweight and $2.3 \%$ obese children 13 years old showed that $20.3 \%$ are overweight and $4.2 \%$ obese, while 15 years of age $11.8 \%$ of children were overweight and $2.5 \%$ obese. The prevalence of overweight was significantly higher in the city (18.5\%) than in rural areas (7.6\%), higher in males compared with females and higher in private schools (23.3\%) compared to public ones (14.1\%). Conclusion: Dietary habits and lifestyle are determinant factors in the prevalence of obesity and overweight in children.
\end{abstract}

Keywords: obesity, overweight, prevalence, nutrition, children, school, city, village, Tirana

\section{Background}

Overweight and Obesity in childhood is seen as one of the greatest challenges of public health for the 21 st century ${ }^{(1)}$. Obesity is characterized by an excessive accumulation of adipose tissue, an increase in body weight and therefore the risk to health is not good ${ }^{(2,3)}$. Its nutrition and lifestyle are important factors for the security and protection of health during adolescence and throughout life. Their role is important for the prevention and control of disease, mortality from chronic diseases. Obesity is a multifactorial nature, it can damage every system of the body of the child, heart, muscles, bones, kidneys and digestive tract, as hormones that control blood sugar and puberty. He is accompanied by a heavy social cost and emotional in children ${ }^{(4)}$. Moreover, young people who are overweight or obese are more likely to be overweight or obese in adulthood (5), thereby increasing their risk for illness or disability during their lifetime.

Among the main risk behaviors that contribute to overweight and obesity surely mention: excessive consumption of foods, especially those with high energy density ${ }^{(3-6)}$, the habit of not eating breakfast ${ }^{(7 / 8)}$, insufficient consumption day of fruits and vegetables ${ }^{(9)}$, little practice of physical activity, both at school and during free time, whether or weekdays and weekends (10/11) increased sedentary lifestyle among which the use of TV computer, play-station, X-Box ${ }^{(12 / 13)}$, a phenomenon encountered especially in children and adolescent ${ }^{(14-15)}$. Growth factors of obesity, registered in recent years, are growing from year to year. On the one hand it comes to habits and modifiable risk factors that attributed to individual behavior ${ }^{(16)}$ which however are related to the complex dynamics of the collective, including friends, family, institutions, and even social organizations and the mass media ${ }^{(17)}$.

\section{Global trend of obesity in children}

In the past three decades, the level of obesity in the US has tripled and today the country has one of the highest levels in the world of overweight and obesity, one in six children is obese and one in three children is overweight or obese ${ }^{(18)}$ Since 2008, this rate has remained unchanged, then some groups have continued to see growth, while some groups have levels of la, Seta RTA others. In 1970, 5\% of children 2-18 years were obese (as defined by the CDC today for obesity), in 2008, approximately $17 \%$ of children were obese, a percentage which has remained unchanged in $2010^{(}$ $18,19)$. Canada is also noticed an increase in obesity among children, since the 70s, in general, obesity has doubled and even tripled in some groups ${ }^{(20)}$. In 2007-2008 about 9\% of 


\section{International Journal of Science and Research (IJSR) \\ ISSN (Online): 2319-7064 \\ Index Copernicus Value (2013): 6.14 | Impact Factor (2015): 6.391}

Canadian children aged 6-17 years were obese, based on the values of the IOTF's limit. Although the data for Latin America and the Caribbean are scarce, it is clear that overweight and obesity childish age has become a significant problem, because in general in the region has more children overweight than underweight. Put in figures, 7 percent of children aged under five years, in 2010, resulted overweight or obese, compared to a reduction of significant underweight from 7 percent in 1990 to 3 percent in $2010^{(21,}$ 22 ), referring to rising standards of WHO.

Hunger, backwardness growing underweight and have been present in children in Africa, fighting even today, where 2025 percent of preschool children in sub-Saharan Africa are underweight ${ }^{(2)}$. However the level of obesity is increasing. Thus, the number of preschool children overweight and obese in the past two decades more than doubled from 4 percent in 1990 to 8.5 percent in 2010, a figure particularly sensitive to North Africa, where one in six children is overweight or obese. ${ }^{(21)}$. With regard to Europe, from the analysis of the available data it is noted that in the past two decades the level of obesity among children in many countries has increased ${ }^{(23,24)}$. Overweight and obesity of children aged 4 years, measured in 27 European countries showed differences between them, with prevalence highest encountered in Spain (32 percent) and the lowest value in Romania by 12 percent (24). Cyprus, Greece, Spain and England appear with the highest level of obesity among children aged 10-18 years to 30 countries studied ${ }^{(23)}$. But again the data are limited and qualitatively different. As for school-age children 6-9.9 years, Initiative of the World Health Organization to assess the age of child obesity, has recently started to follow the levels of obesity in children in about 15 countries, using standards of raising children WHO.

The first analysis, based on data from the years 2007-2008 to 13 countries, revealed that 24 percent of children aged 6-9 years are overweight, being encountered in an interval from $19 \%$ to $49 \%$ among boys and from $18 \%$ to $43 \%$ among girls, and a range of obesity by $6 \%$ to $26.6 \%$ among boys and from $5 \%$ to $17 \%{ }^{(25)}$ among girls. With high prevalence of obesity was observed in Italy, Portugal and Slovenia (based on child growth references to WHO, 2007). ${ }^{(26)}$

\section{The situation of overweight and obesity in Albania}

In Albania, overweight and obesity are important risk factor for health, especially for non-communicable diseases. Details of a study conducted by IPH ${ }^{(27)}$ showed that $15.2 \%$ of children aged 9-10 years are overweight, of which 3.8\% are obese. The ADHS's data, 2008- 2009, revealed that about 22 percent of children aged under five years are overweight or obese, while among adults 15 and older, 53\% of men aged 15-49 were overweight (of which 9\% obese) and 39\% of women of the same age group resulted overweight (of which $10 \%$ obese), ${ }^{(28)}$. The data above show that even young children obesity rate is increasing across the globe. Preventing obesity in the early years of life (even before birth through healthy habits during pregnancy) confirms a healthy life. And this is the most promising way to reverse the global epidemic. ${ }^{(29)}$. The most troubling aspect of obesity in children is that these children remain obese in adulthood, developing more serious pathologies that tend to lead to a reduction of quality and longevity. In fact, habits acquired in childhood, related to diet and physical activity throughout life do not change easily. Therefore prevention and curbing rising obesity at the age of childish presents today a challenge for public health, because it is very hard to tackle the obesity installed, is very high probability of being a teenager or adult obese, it is difficult to correct habits wrong nutrition in adults, acquired in childhood ${ }^{(27)}$. The need to follow closely the nutritional situation and habits of life of the population in general and children in particular motivated by their implications directly on children's health, and because they represent risk factors for the emergence of obesity and pathologies age increased.

Health indicators of nutrition in our country before 1990 have been somewhat satisfactory, but after 1990, Albania passed in a process of transition, the cause which led to the amount changes this is related to factors nutrition and lifestyle jeteës children and teens. Also, economic development, urbanization and globalization of the market have brought about a kind of "nutritional transition", which is characterized by changes in both quality and quantity of dietary factors and some "modernization" of the manner or style of living. To assess these changes in nutrition and its relationship with demographic characteristics, lifestyle elements have carried out a study in children and adolescents 11, 13,15 years in Tirana schools (public / nonpublic, urban / rural ) during the period October 2014March 2015

\section{The aim of the study}

- Assessment of nutritional status of a group of children aged 11-13-15 years old district of Tirana (overweight and obesity)

- Assessment of children's body image by BMI indicator that

\section{The objective of the study}

Objective: Evaluation of the prevalence of obesity, overweight, underweight children in developing age 11-1315 years.

\section{Survey Methodology /Type of Study}

Transversal (cross-sectional), I prospectiv two component type; Descriptive, this component refers to description / assessment of the prevalence and distribution of risk factors and analytical in order to assess the connection (association) of food items with demographic, socio-economic and lifestyle. Transversal studies are only studies that assess directly the prevalence of risk factors in the population.

\section{Population study}

The sampling method used is stratified sampling in clusters, in accordance with the size of the population, recommended by WHO / UNICEF. The selection method according to residence (urban / rural) and type of school was based on the size of the target population. Type of school (public / private) was not considered in the selection layer, but a variable in the analysis, because the layer "rural", not the type of school represented "Private". 


\section{International Journal of Science and Research (IJSR) \\ ISSN (Online): 2319-7064 \\ Index Copernicus Value (2013): 6.14 | Impact Factor (2015): 6.391}

\section{Collection of data}

Data collection was made possible through a physical examination and a semi-structured questionnaire selfadministered, which was distributed to students of the 9year-old. The methods used to perform anthropometric measurements were those recommended by WHO. Physical examination included the weight and length. Each child was measured separately, in a peaceful environment in order to avoid discomfort. Based on the children's height and weight, was calculated BMI, body mass index as a ratio of weight (in $\mathrm{kg}$ ) and height (in meters squared).

The questionnaire contained several questions that provide the nutritional knowledge inforrmacion on subjects related behaviors and nutrition information, etc. perception of body image. Before completing the questionnaire any subject you became indicators anthropometric measurement, weight / length. (Using the "Seca" stadiometer by UNICEF with a sensitivity of $0.1 \mathrm{~cm}$ and $0.1 \mathrm{~kg}$, respectively).

\section{Statistical Analysis}

Univariate analysis followed by bivariate analysis by residence (urban / rural), gender, age, etc. The analysis was conducted with the help of statistical package SPSS 20.0 and M.Office.Excel 2010.Vlerësimi The prevalence of overweight and obesity was referring Internationale standards for Obesity Task Force. ${ }^{(30)}$ For the collection of information that had to do with acquaintances nutrition of children, their customs and nutritional values were assessed through survey questions on the extent of their knowledge about nutrition, orientation linked to the consumption of food that meals consuming, knowledge about food Hello jot healthier and healthier, if you provided information on food and nutrition as would prefer to have it, feeding habits, etc. While perceptions about the image body, children were offered 7 (seven) different pictures to compare the appearance of its own with one of the figures that he / she resembled more, if you feel good or not their appearance or would like to improve it.

\section{Results}

Distribution village / city of the children Were Involved in the study 362 children in the respective values of the city and 158 from the village (Table 1).

Table 1: Population Involved in the study by residence

\begin{tabular}{|c|c|c|}
\hline Location/ city/village & Frequency in number & Frequency in \% \\
\hline City & 362 & 69,6 \\
\hline Village & 158 & 30,4 \\
\hline Total & 520 & 100,0 \\
\hline
\end{tabular}

Ratio male / female was almost the same, where 259 children were males and 261 females (Table 2).

Table 2: Involved in the study population by sex

\begin{tabular}{|c|c|c|}
\hline Gender & Frequency in number & Frequency in \% \\
\hline MALE & 259 & 49,8 \\
\hline FEMALE & 261 & 50,2 \\
\hline Total & 520 & 100,0 \\
\hline
\end{tabular}

Children as young as 13 were slightly more (37\%) of children aged 11 and 15 years (Table 3).

Table 3: Included in the study population by age

\begin{tabular}{|c|c|c|}
\hline Age of children & Frequency in number & Frequency in \% \\
\hline 11 years & 168 & 32,3 \\
\hline 13 years & 192 & 37,0 \\
\hline 15 years & 160 & 30,7 \\
\hline Total & 520 & 100,0 \\
\hline
\end{tabular}

To determine the state of overweight and obesity in this study uses indirect indicator of the evaluation of this situation BMI (Body Mass Index). To determine underweight, normal, overweight and obese children were selected to be used as the limit values set by the WHO (World Health Organization) from IOTF-i (International Obesity Task Force). Data from the analysis of anthropometric (weight and height measurement for each child) showed that the prevalence of overweight in children aged 11-15 years in Tirana was $15.2 \%$ in value and $3.1 \%$ prevalence of obesity. The rest of the children (84.8\%) of them were normal or underweight (Table 4).

Table 4: The nutritional status of children under the Body Mass Index

\begin{tabular}{|c|c|c|}
\hline BMI & Frequency in number & Frequency \% \\
\hline overweight $*$ & 79 & 15.2 \\
\hline Obese & 16 & 3.1 \\
\hline underweight or normal & 425 & 84.8 \\
\hline Total & 520 & 100 \\
\hline
\end{tabular}

*overweight, including obese

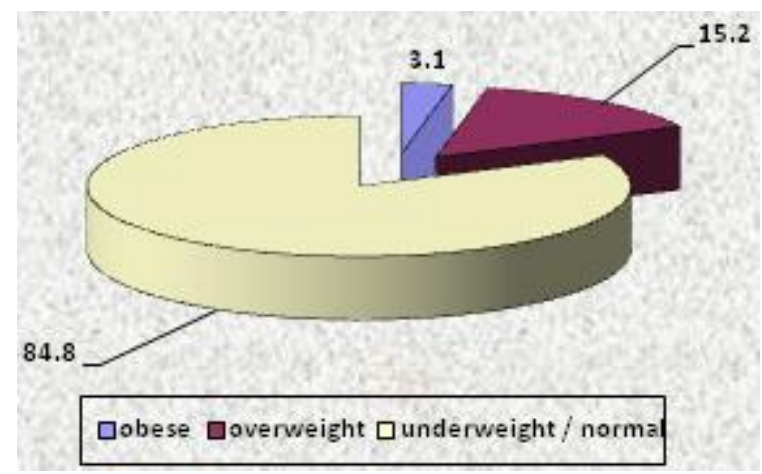

Diagram 1: Distribution of the nutritional status of children (in\%) according to the Body Mass Index BMI in Tirana.

The data showed a higher prevalence of obesity in urban areas compared to rural him over double. While there was no obese children in the village versus 16 obese children in the city (Table 5 .

Table 5: Body mass index by school location

\begin{tabular}{|c|c|c|c|}
\hline \multirow{2}{*}{ BMI } & \multicolumn{2}{|c|}{ Location of school } & \multirow{2}{*}{ Total } \\
\cline { 2 - 3 } & City & Village & \\
\hline \multirow{2}{*}{ overweight * } & 67 & 12 & 79 \\
\cline { 2 - 4 } & $\mathbf{1 8 , 5 \%}$ & $7,6 \%$ & $15.20 \%$ \\
\hline \multirow{2}{*}{ Obese } & 16 & 0 & 16 \\
\cline { 2 - 4 } & $\mathbf{4 , 4 \%}$ & $\mathbf{0 \%}$ & $3.10 \%$ \\
\hline \multirow{2}{*}{$\begin{array}{c}\text { underweight } \\
\text { or normal }\end{array}$} & 279 & 146 & 425 \\
\cline { 2 - 4 } Total & $81.50 \%$ & $92,4 \%$ & $84.80 \%$ \\
\cline { 2 - 2 } & 362 & & 520 \\
\cline { 2 - 2 } & $100,0 \%$ & & $100,0 \%$ \\
\hline
\end{tabular}

* overweight, including obese 


\section{International Journal of Science and Research (IJSR) \\ ISSN (Online): 2319-7064 \\ Index Copernicus Value (2013): 6.14 | Impact Factor (2015): 6.391}

The number of overweight children in private schools (23.3\%) was about 2 times higher than in public schools (14.1\%), so is the difference of obese children in the respective schools (5.0\% to $2,8 \%$ ) (Table 6 ).

Table 6: Body mass index of children by type of school

\begin{tabular}{|c|c|c|c|c|}
\hline \multirow{2}{*}{ Type of school } & \multicolumn{3}{|c|}{ BMI } & \multirow{2}{*}{} \\
\cline { 2 - 5 } & Overweight $*$ & Obese & $\begin{array}{c}\text { Underweight } \\
\text { or Normal }\end{array}$ & Total \\
\hline \multirow{3}{*}{ PUBLIC } & 65 & 13 & 382 & 460 \\
\cline { 2 - 5 } & $14,1 \%$ & $2,8 \%$ & $83,0 \%$ & $100.0 \%$ \\
\hline NONPUBLIC & 14 & 3 & 43 & 60 \\
\cline { 2 - 5 } & $23,3 \%$ & $5,0 \%$ & $71,7 \%$ & $100.0 \%$ \\
\hline \multirow{2}{*}{ Total } & 79 & 16 & 425 & 520 \\
\cline { 2 - 5 } & $15.2 \%$ & $3.1 \%$ & $84.8 \%$ & $100.0 \%$ \\
\hline
\end{tabular}

* overweight, including obese

Overweight or obesity in children aged 13 years old was higher than children aged 11 and 15 years (Table 7)

Table 7: body mass index of children by age group

\begin{tabular}{|c|c|c|c|c|}
\hline \multirow{2}{*}{ Age } & \multicolumn{3}{|c|}{ Body mass index BMI } & \\
\cline { 2 - 5 } & Overweight $*$ & Obese & $\begin{array}{c}\text { Underweight or } \\
\text { Normal }\end{array}$ & Total \\
\hline \multirow{2}{*}{11 years } & 21 & 4 & 143 & 168 \\
\cline { 2 - 5 } & $12.50 \%$ & $2.30 \%$ & $85.20 \%$ & $100.00 \%$ \\
\hline \multirow{2}{*}{13 years } & 39 & 8 & 145 & 192 \\
\cline { 2 - 5 } & $20.30 \%$ & $4.20 \%$ & $75.50 \%$ & $100.00 \%$ \\
\hline \multirow{2}{*}{15 years } & 19 & 4 & 137 & 150 \\
\cline { 2 - 5 } & $11.80 \%$ & $2.50 \%$ & $85.60 \%$ & $100.00 \%$ \\
\hline \multirow{2}{*}{ Total } & 79 & 16 & 425 & 520 \\
\cline { 2 - 5 } & $15.20 \%$ & $3.10 \%$ & $84.80 \%$ & $100.00 \%$ \\
\hline
\end{tabular}

Boys were more overweight than girls met while obesity significantly more boys (5.0\%) than girls (1.1\%) (Table 8$)$.

Table 8: body mass index of children by sex

\begin{tabular}{|c|c|c|c|c|}
\hline \multirow{2}{*}{ Gender } & \multicolumn{3}{|c|}{ Body mass index } & \multirow{2}{*}{ Total } \\
\cline { 2 - 4 } & $\begin{array}{c}\text { Overweight } \\
*\end{array}$ & Obese & $\begin{array}{c}\text { Underweight } \\
\text { or Normal }\end{array}$ & \\
\hline \multirow{2}{*}{ MALE } & 46 & 13 & 200 & 259 \\
\cline { 2 - 4 } & $\mathbf{1 7 , 8 \%}$ & $5,0 \%$ & $82.20 \%$ & $100,0 \%$ \\
\hline \multirow{2}{*}{ FEMALE } & 33 & 3 & 225 & 261 \\
\cline { 2 - 5 } & $\mathbf{1 2 , 6 \%}$ & $1,1 \%$ & $87.40 \%$ & $100,0 \%$ \\
\hline \multirow{2}{*}{ Total } & 79 & 16 & 425 & 520 \\
\cline { 2 - 4 } & $15.20 \%$ & $3.10 \%$ & $84.80 \%$ & $100.00 \%$ \\
\hline
\end{tabular}

* overweight, including obese

General question about the extent of their knowledge about nutrition, 26.2\% (about 1/4) of them responded to know little or not at all know, about $31.5 \%$ of them claim to know a few things and about $23.7 \%$ know a lot about nutrition, not respond (0.6\%) Dagram 2)

* overweight, including obese

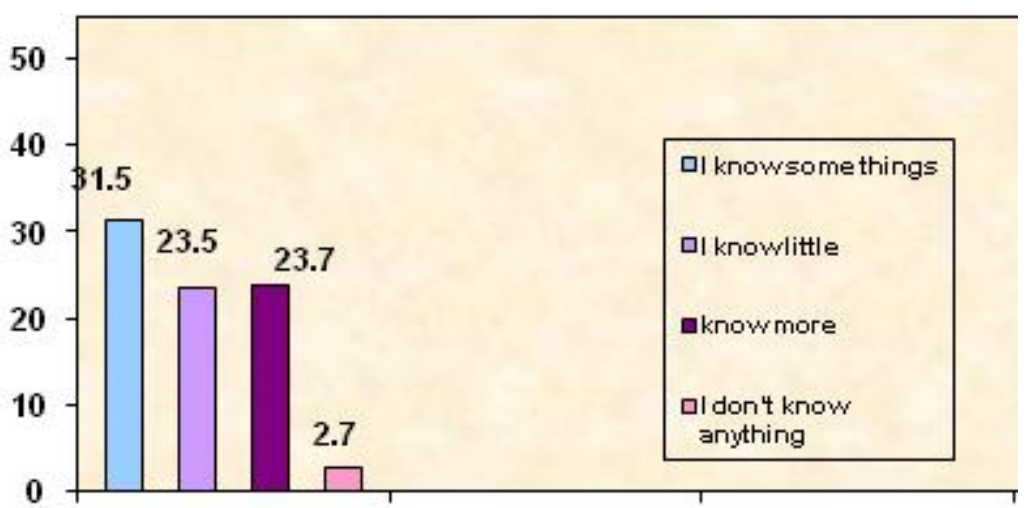

Diagram 2: The level of knowledge about nutrition (\%), according to the perception of children

Question: "I think you need to eat less or more, children did not oppose the following

(Diagram 3) showing that they have a good understanding of the food good or harmful. 


\section{International Journal of Science and Research (IJSR) \\ ISSN (Online): 2319-7064}

Index Copernicus Value (2013): 6.14 | Impact Factor (2015): 6.391

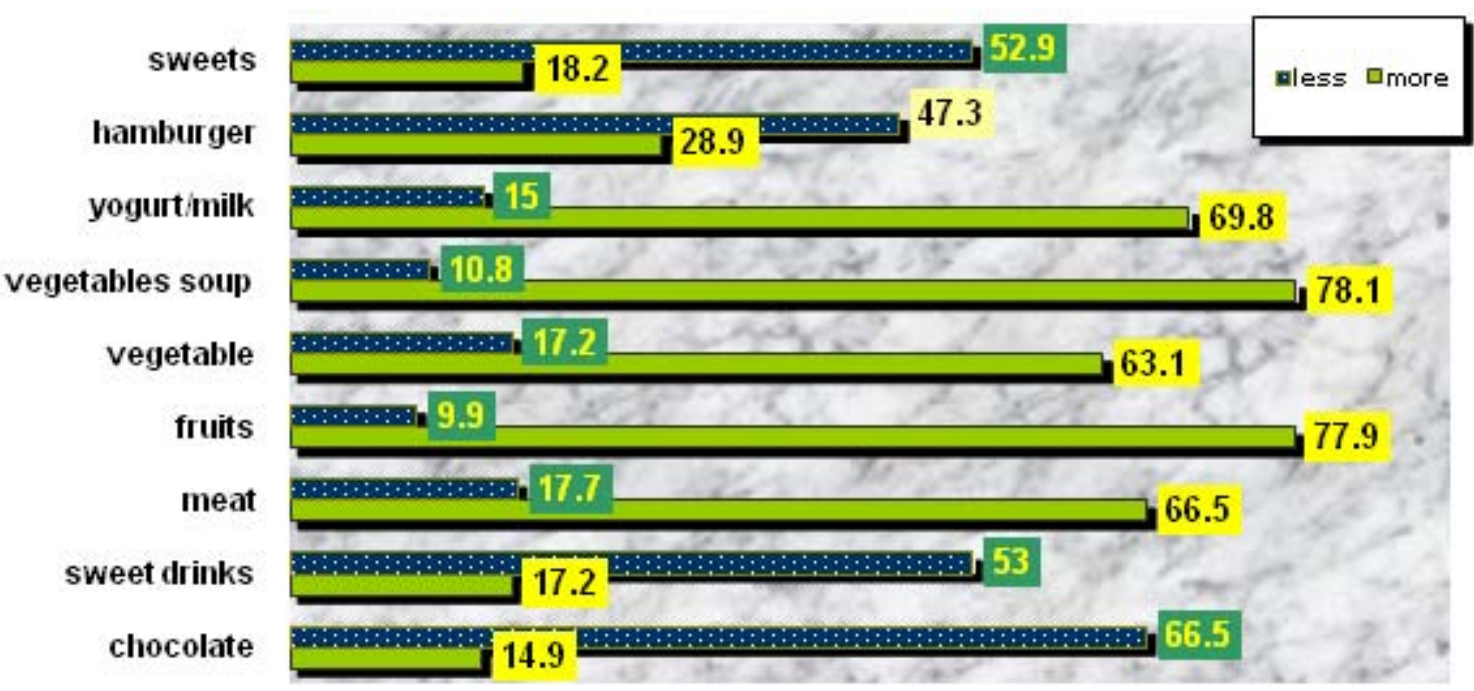

Diagram 3: Orientation associated with the consumption of certain foods and beverages

\section{I think that should be consumed}

Question: "In your opinion who should consume meals to healthy adults ?, $90.6 \%$ of children think that to be healthy is very important breakfast consumption, $87 \%$ say yes to lunch consumption and $84.9 \%$ supper. Less important intermediate meals they see as the morning (23\%) in the afternoon (30\%), ignoring the principle of after-dinner meal. However $45.5 \%$ feed their morning, afternoon $57.3 \%$ and $24 \%$ of children in the evening (Diagram 4). While breakfast consume about $87 \%$ of them.

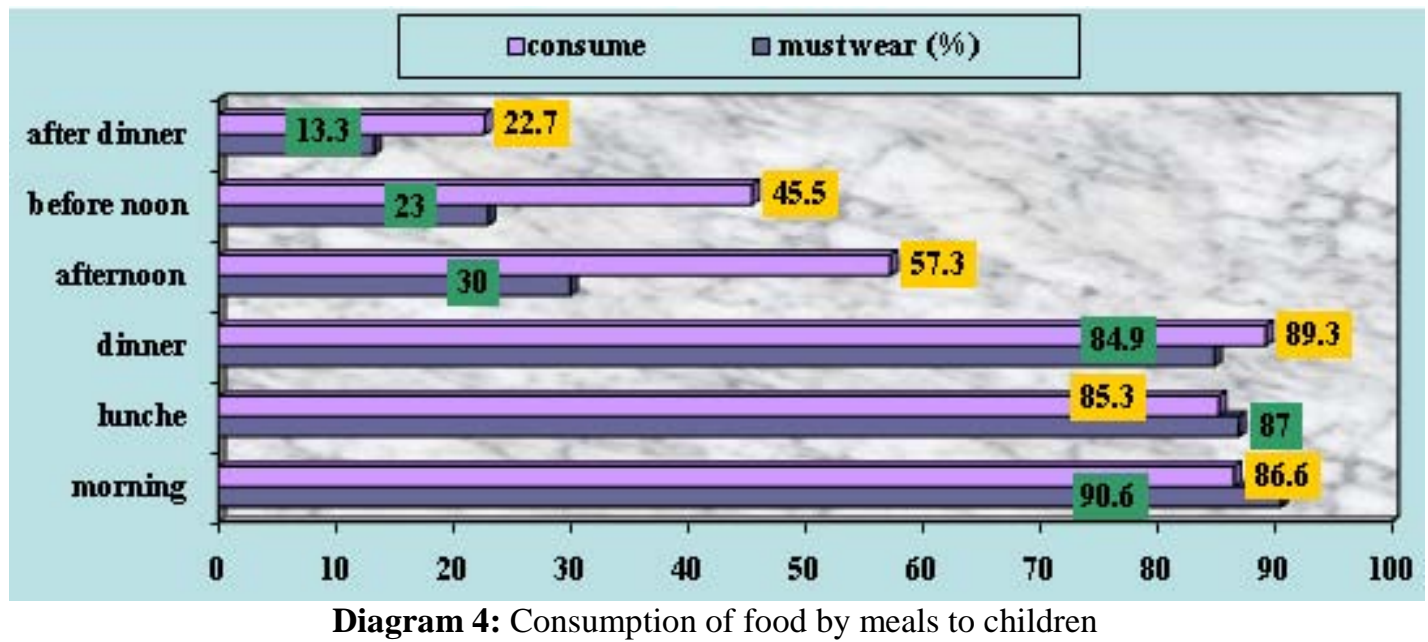

Regarding food healthy children have satisfactory knowledge on what you do well in most foods like fruits and vegetables, milk, soup, etc. but $65 \%$ do not think that cereals are also healthy and about $42 \%$ of them. They think that the fish is not so. (Diagram5) 


\section{International Journal of Science and Research (IJSR)}

ISSN (Online): 2319-7064

Index Copernicus Value (2013): 6.14 | Impact Factor (2015): 6.391

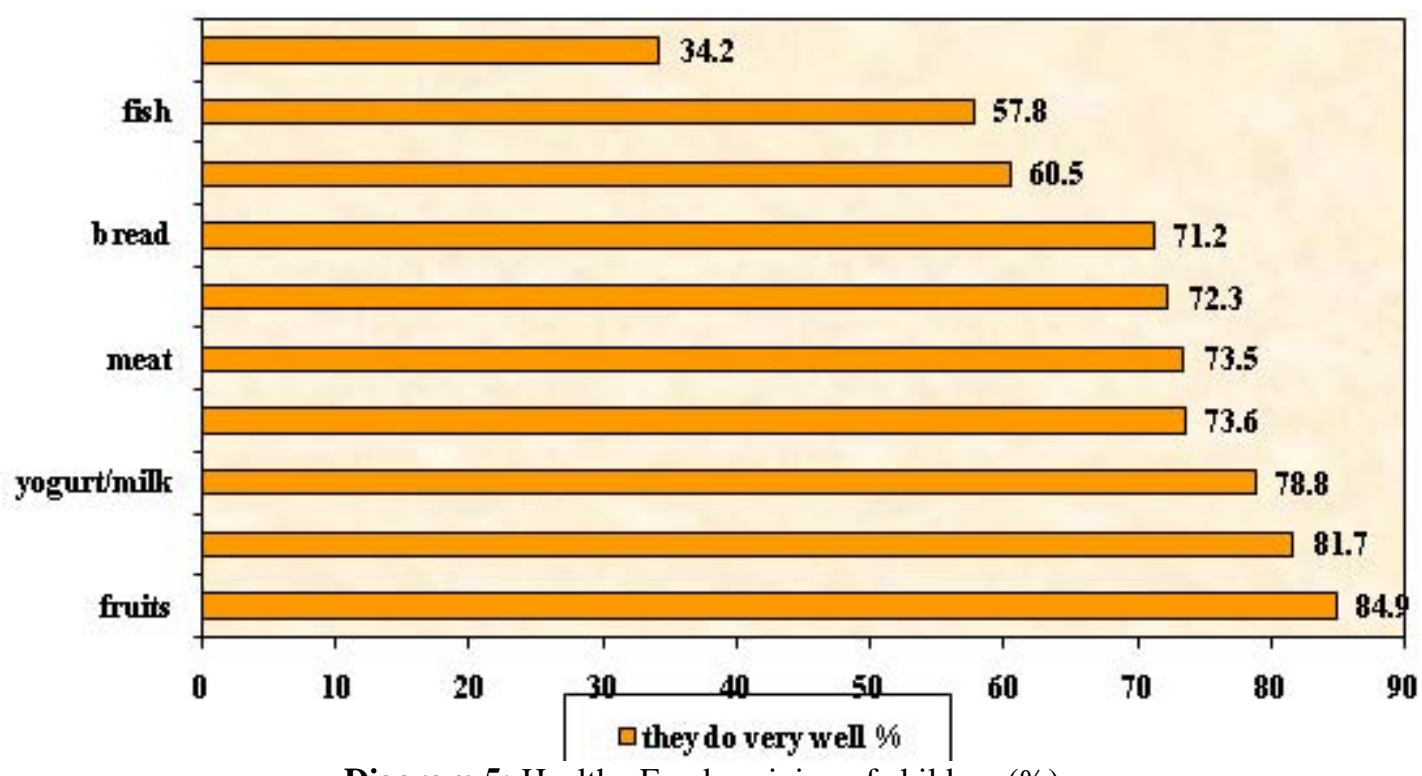

Diagram 5: Healthy Foods opinion of children (\%).

To unhealthy foods, only $16 \%$ of margarine see children as unhealthy food, $24.9 \%$ of them think that there is such hamburger. Ordering food starts with sweet unhealthy processed (chocolate, sugar, sweets) being followed by much less chips, burgers, margarine, etc. Children share half thought of cakes and ice cream. Not only food but also the nutrients needed for a healthy body partially recognize children (Table 9).

Table 9: The human body needs *:

\begin{tabular}{|l|c|c|c|}
\hline Nutrients & number of answers & Yes (\%) & No (\%) \\
\hline Protein & 520 & $67.5 \%$ & $32.5 \%$ \\
Fats & 520 & $12.8 \%$ & $87.2 \%$ \\
Iron & 520 & $52.7 \%$ & $47.3 \%$ \\
Vitamins & 520 & $93.1 \%$ & $6.9 \%$ \\
Salt & 520 & $10.9 \%$ & $89.1 \%$ \\
Fiber & 520 & $43.9 \%$ & 56.15 \\
Calorie & 520 & $48.5 \%$ & $51.5 \%$ \\
Calcium & 520 & $56.3 \%$ & $43.7 \%$ \\
water & 520 & $65.6 \%$ & $37.4 \%$ \\
\hline
\end{tabular}

* question with multiple answers

When children were asked who were the main factors affecting their way of feeding 3\% do not know how to tell them what factors influence the selection of food. While about $2 / 3$ of children put as the most important factors taste and then parents. Taste factor explains to some extent the difficulty of categorizing these children unhealthy foods. About $42 \%$ are attracted by surprises and less than $40 \%$ of food advertising.

If would be given information on food and nutrition, they would prefer to have it by $48.5 \%$ of children magazines, television programs $28.5 \%$, from $14.4 \%$ educational material, from $7.7 \%$ culinary courses, and very few would want of informative material $(0.6 \%)$ or visits to manufacturing enterprises (0.4\%).

On nutritional habits and report their daily food on the table, the children claimed that $74 \%$ of them "prefer foods that increase appetite", 39.1\% of "difficult to eat different kinds of food," 59\% of children " I love to eat between meals ", only $19.3 \%$ said that" the moment of eating is very difficult for them ", 42.8\% are very interested" in the quantity rather than the quality of the food they consume ", 1/3 (32.9\%) of them will "prefer to eat outside".

It is well worth reporting their children's nutritional habits linked to a series of questions as follows:

Table10: I eat particular foods that increase appetite

\begin{tabular}{|c|c|c|}
\hline & Frequency in number & Frequency in \% \\
\hline TRUE & 377 & 72,6 \\
\hline FALSE & 142 & 27,4 \\
\hline Total & 519 & 100,0 \\
\hline
\end{tabular}

Table 11: I love to eat between meals

\begin{tabular}{|c|c|c|}
\hline & Frequency in number & Frequency in \% \\
\hline TRUE & 295 & 56,8 \\
\hline FALSE & 224 & 43,2 \\
\hline Total & 519 & 100,0 \\
\hline
\end{tabular}

Table 12: I like to try different types of food

\begin{tabular}{|c|c|c|}
\hline & Frequency in number & Frequency in \% \\
\hline TRUE & 436 & 84,5 \\
\hline FALSE & 80 & 15,5 \\
\hline Total & 516 & 100,0 \\
\hline
\end{tabular}

Tabele 13: Moment of the dining table is difficult for me, I do not like to eat

\begin{tabular}{|c|c|c|}
\hline & Frequency in number & Frequency in \% \\
\hline True & 81 & 15,7 \\
\hline False & 435 & 84,3 \\
\hline Total & 516 & 100,0 \\
\hline
\end{tabular}

Table 14: I'm more attentive to the quality rather than the quantity of its food

\begin{tabular}{|l|c|c|}
\hline & Frequency in number & Frequency in \% \\
\hline True & 203 & 39,8 \\
\hline False & 307 & 60,2 \\
\hline Total & 510 & 100,0 \\
\hline
\end{tabular}




\section{International Journal of Science and Research (IJSR) \\ ISSN (Online): 2319-7064 \\ Index Copernicus Value (2013): 6.14 | Impact Factor (2015): 6.391}

Table 15: I like to eat the same things

\begin{tabular}{|l|c|c|}
\hline & Frequency in number & Frequency in \% \\
\hline True & 123 & 23,7 \\
\hline False & 395 & 76,3 \\
\hline Total & 518 & 100,0 \\
\hline
\end{tabular}

Table 16: I like to eat out, (not at home)

\begin{tabular}{|l|c|c|}
\hline & Frequency in number & Frequency in \% \\
\hline True & 167 & 32,2 \\
\hline False & 351 & 67,8 \\
\hline Total & 518 & 100,0 \\
\hline
\end{tabular}

Table 17: Ha give me everything that

\begin{tabular}{|l|c|c|}
\hline & Frequency in number & Frequency in \% \\
\hline True & 259 & 49,9 \\
\hline False & 260 & 50,1 \\
\hline Total & 519 & 100,0 \\
\hline
\end{tabular}

Delivers the values associated with the consumption of fruits and vegetables children are almost all agree (96.9\%) than fruits and vegetables in health benefit.

Table 18: Fruits and vegetables not healed

\begin{tabular}{|c|c|c|}
\hline & Frequency in number & Frequency in \% \\
\hline YES & 207 & 39,8 \\
\hline NO & 297 & 57,1 \\
\hline I do not know & 16 & 3,1 \\
\hline Total & 520 & 100,0 \\
\hline
\end{tabular}

Table 19: Fruits and vegetables weaken

\begin{tabular}{|l|c|c|}
\hline & Frequency in number & Frequency in \% \\
\hline YES & 64 & 12,3 \\
\hline NO & 440 & 84,6 \\
\hline I do not know & 16 & 3,1 \\
\hline Total & 520 & 100,0 \\
\hline
\end{tabular}

\section{The perception of body image}

Children questionnaires also provided information regarding the perception of body image from his children .The following are associated with children's perceptions of their physical appearance based on 7 different figures that were shown every child to compare its appearance with one of those figures that he / she resembled more. Children have an accurate perception of their body image. About $87 \%$ of obese children report that they feel like themselves, while $12.5 \%$ think they are overweight. While overweight among children around half (47\%) consider themselves as such against $10.4 \%$ who think they are normal, and 33\% think they are obese. (Table 17)

The following are associated with children's perceptions of their physical appearance based on 7 (seven) different figures that were shown every child to compare its appearance with one of those figures that he / she resembled more. Children have an accurate perception of their body image. About $87 \%$ of obese children report that they feel like themselves, while $12.5 \%$ think they are overweight. While overweight among children around half (47\%) consider themselves as such against $10.4 \%$ who think they are normal, and 33\% think they are obese. (Table 17)

Table 20: Assessment of body image of children by their mass index body, BMI

\begin{tabular}{|c|c|c|c|c|c|c|c|c|}
\hline \multirow{3}{*}{ BMI } & \multicolumn{7}{|c|}{ Who of the figures is similar to you? } & \multirow{3}{*}{ Total } \\
\hline & Figure 1 & Figure 2 & Figure 3 & Figure 4 & Figure 5 & Figure 6 & Figure 7 & \\
\hline & $\begin{array}{c}\text { underweigt } \\
\text { III }\end{array}$ & $\begin{array}{c}\text { underweigt } \\
\text { II }\end{array}$ & $\begin{array}{c}\text { underweigt } \\
\text { I }\end{array}$ & Normal & overweight I & Obese I & Obese I & \\
\hline \multirow{3}{*}{ Overweight } & 0 & 0 & 7 & 8 & 36 & 22 & 4 & 77 \\
\hline & ,0\% & ,0\% & $9,1 \%$ & $10,4 \%$ & $46,8 \%$ & $28,6 \%$ & $5,2 \%$ & $100,0 \%$ \\
\hline &, $0 \%$ &, $0 \%$ & $9,0 \%$ & $7,9 \%$ & $18,7 \%$ & $29,3 \%$ & $28,6 \%$ & $15,7 \%$ \\
\hline \multirow{3}{*}{ Obese } & 0 & 0 & 0 & 0 & 2 & 11 & 3 & 16 \\
\hline &, $0 \%$ & $0 \%$ &, $0 \%$ &, $0 \%$ & $12,5 \%$ & $68,8 \%$ & $18,8 \%$ & $100,0 \%$ \\
\hline & $0 \%$ &, $0 \%$ &, $0 \%$ &, $0 \%$ & $1,0 \%$ & $14,7 \%$ & $21,4 \%$ & $3,3 \%$ \\
\hline \multirow{3}{*}{$\begin{array}{l}\text { Underweigt } \\
\text { or normal }\end{array}$} & 13 & 17 & 71 & 93 & 155 & 42 & 7 & 398 \\
\hline & $3,3 \%$ & $4,3 \%$ & $17,8 \%$ & $23,4 \%$ & $38,9 \%$ & $10,6 \%$ & $1,8 \%$ & $100,0 \%$ \\
\hline & $100,0 \%$ & $100,0 \%$ & $91,0 \%$ & $92,1 \%$ & $80,3 \%$ & $56,0 \%$ & $50,0 \%$ & $81,1 \%$ \\
\hline \multirow{3}{*}{\multicolumn{2}{|c|}{ Total }} & 13 & 17 & 78 & 101 & 193 & 75 & 14 \\
\hline & & $2,6 \%$ & $3,5 \%$ & $15,9 \%$ & $20,6 \%$ & $39,3 \%$ & $15,3 \%$ & $2,9 \%$ \\
\hline & & $100,0 \%$ & $100,0 \%$ & $100,0 \%$ & $100,0 \%$ & $100,0 \%$ & $100,0 \%$ & $100,0 \%$ \\
\hline
\end{tabular}

Also note that they do not feel good about their appearance and would like to improve it. And overweight children want to $31.4 \%$ of them are normal, $12.9 \%$ want to be weak, $8.6 \%$ to be very weak, but by that they want to remain as they are
(37.1\%) while 13\% They want to be healthier than they are (diagram 6) 


\section{International Journal of Science and Research (IJSR) \\ ISSN (Online): 2319-7064}

Index Copernicus Value (2013): 6.14 | Impact Factor (2015): 6.391

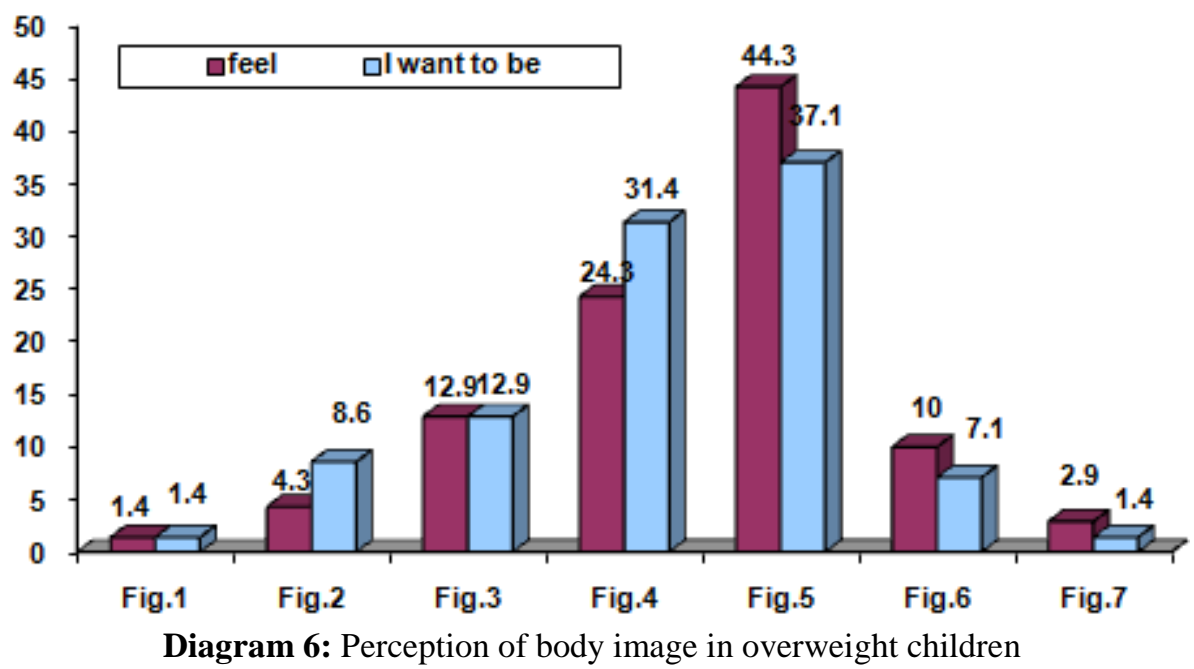

Obese children also want to be very weak from the poor (31.2\%). There are also those that feel good to maintain the same condition (12.5\%) or weaken slightly (ie $13.8 \%$ change the look of their body towards a more improved. (Diagram 7). overweight). It is important that obese children 3 to 5 to

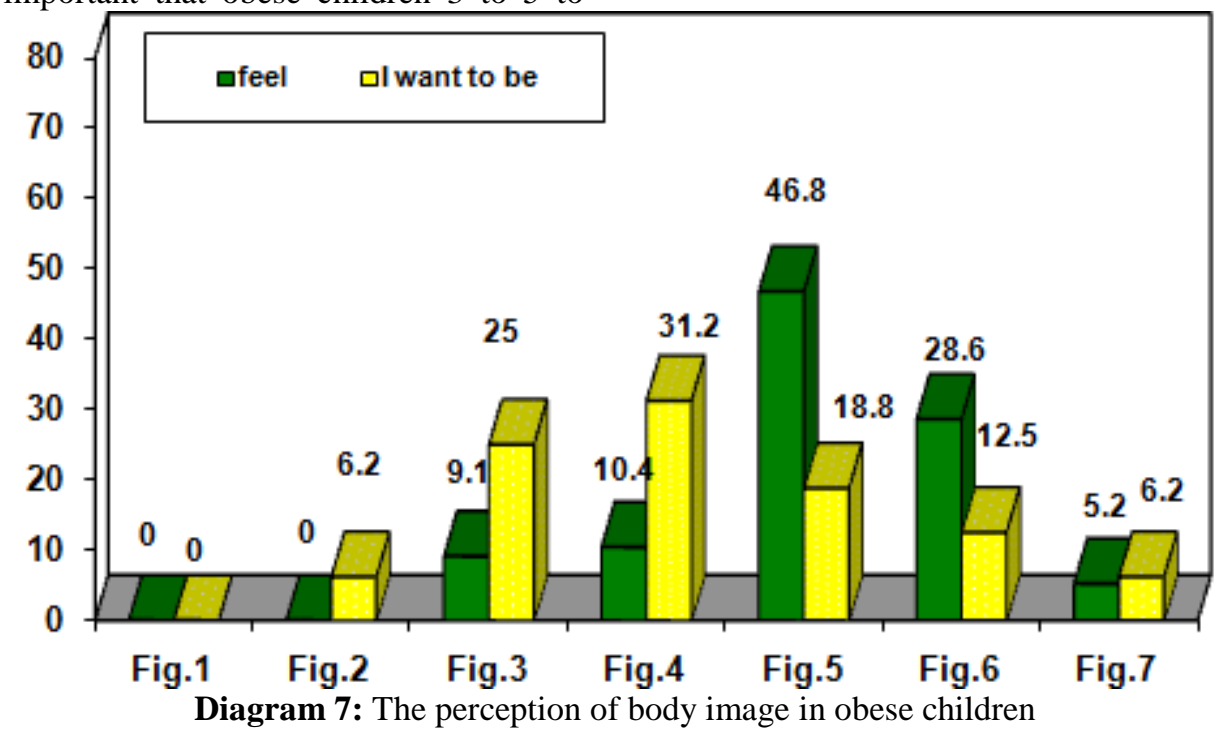

\section{Conclusions}

Our data highlighted that $15.2 \%$ of children were overweight and $3.1 \%$ were obese, and according to age groups surveyed for children 11 years old showed $12.5 \%$ were overweight and $2.3 \%$ obese children 13 years old showed that $20.3 \%$ are overweight and $4.2 \%$ obese, while 15 years of age $11.8 \%$ of children were overweight and $2.5 \%$ obese. The prevalence of overweight was significantly higher in the city (18.5\%) than in rural areas (7.6\%), higher in males compared with females and higher in private schools (23.3\%) compared to public ones (14.1\%).

As compared with the prevalence of the 25 states of the EU results of this study tregouan that overweight and obesity in our country are already an evident problem of public health, such as the potential effects, if you think connection with the development of many diseases, among which exemption the potential social group or loss of self-esteem, which can provoke. We are aware that in this delicate phase, corrective actions as keeping a restrictive diet to obesity, may expose some potential risks as the development of frustration, concentration problems and sleep, to delays in development. The study showed that children represent, in general, good knowledge in the field of nutrition, recognizing correctly foods with high nutritional value, compared with those with less nutritional value. The same clearly express preferences that children from "learn about nutrition" in ways that are based on active participation in school culinary courses, educational materials, visits to manufacturing enterprises. Another phenomenon is striking is the high number of children who do not eat breakfast since the morning is one of the most important meals for children, through which they should provide around $20-25 \%$ of their energy needs . Of the most important tools that serve as a source of nutritional information for families, there is very little influence of the physician, school and consumer association in the promotion of knowledge in the field of nutrition. Excess exposure to publicity spots of different food products (products of sweet or sugary conflicting with balanced nutrition and recommended today by various scientific bodies) and with obtaining food hiperkalorike; This combination of factors, the population received the study results important for the value of overweight and obesity found, with consequences 


\section{International Journal of Science and Research (IJSR) \\ ISSN (Online): 2319-7064}

Index Copernicus Value (2013): 6.14 | Impact Factor (2015): 6.391

that are thought to increase with the transition to adolescence.

Noted that children are qualitatively conscious about their body image and do not hesitate to express dissatisfaction and desire to change this image, shown that especially for overweight or obese children. A balanced diet during childhood and adolescence is a fundamental part of good health, especially when eating habits are formed during this period usually followed during aged adult, affecting the development of severe chronic ${ }^{(31)}$ including obesity . These measures should take into account that child nutritional profiles vary from 11 years to 15 years, which shows that this is a key age for developing ndëerhyrjeve broom and that efforts must be sustained.

\section{Recommendations}

The results of our study are comparable to various studies recognized by the WHO, in developing countries and can serve as a benchmark for policy makers. This study may be expanded to include more children and teens. Prevention is the best report cost-benefit for the control of overweight and obesity in developing age, and in the future, the adult age.

Children are considered a priority population for prevention strategies because weight loss in adulthood is difficult and there is a greater number of important interventions for children than for adults. Prevention can be achieved through various interventions that target: environment, diet and physical activity.

- Establishing a sustainable and functional system featuring surveillance incidence and prevalence of overweight and obesity in our population, as well as models of nutrition and physical activity.

- Unlike many experiences to date, the primary school nutrition interventions for healthy promotional, must fall on behavior, not on knowledge, through an active way of obtaining knowledge.

- $\quad$ Reducing the large volume of marketing of foods with high calories, beverages and fast food to children, particularly through the media and television, as Fast Food are the products that you become more advertisement on television, and children are often the market target their.

- Promoting a healthy diet as a primary element for maintaining an optimal weight, combined with increased spending necessarily energy, promoting physical activity and sport.

It is worth remembering that the health of the population depends on only a handful of health services. To grow, the individual and society, need to know and get acquainted with the strengths and so delicate that it can intervene where necessary. Thus, a mutual collaboration between staff of schools and public health matters associated with the periodic assessment of the situation nutrition of children by conducting and analyzing anthropometric measurements may represent an example of cooperation common pursuit of the trend of weight excess in children, the fight against overweight, obesity and risk behaviors in childhood.

\section{Reference}

[1] World Health Organization. Global strategy on diet, physical activity, and health: childhood overweight and obesity. Accessed March 9, 2012

[2] OBSH. Obesity: Preventing and Managing the Global Epidemic. OBSH Technical Report Series No. 894.Geneva: OBSH; 2000.

[3] Branca F., Nikogosian H., Lobstein T. The challenge of obesity in the OBSH European Region and the strategies for response. Summary. Geneva: OBSH; 2007

[4] Ebbeling CB, Pawlak DB, Ludwig DS. Childhood obesity: public-health crisis, common sense cure.Lancet. 2002; 360:473-82.

[5] Singh AS, Mulder C, Twisk JW, van Mechelen W, Chinapaw MJ. Tracking of childhood overweight into adulthood: a systematic review of the literature. Obes Rev. 2008;9:474-88.

[6] Prentice AM, Jebb SA. Fast foods, energy density and obesity: a possible mechanistic link. Obes Rev 2003; 4:187-94.

[7] Ludwig DS, Peterson KE, Gortmaker SL. Relation between consumption of sugarsweetened drinks and childhood obesity: a prospective, observational analysis. Lancet 2001;357:505-8.

[8] Giovannini M, Verduci E, Scaglioni S, Salvatici E, Bonza M, Riva E, Agostoni C. Breakfast: a good habit, not a repetitive custom. J Int Med Res 2008; 36:613-24.

[9] OBSH. Strategic objective 9: "To improve nutrition food safety and food security throughout the lifecourse and in support of public health and sustainable development". Geneva: OBSH; 2008. http://www.euro.OBSH.int/_data/assets/pdf_ file/0018/140661/CorpBrochure_Nutritious_food.pdf; ultima consultazione 3/5/2012.

[10]OBSH. Diet and physical activity: a public health priority. Geneva: OBSH; 2006. www.OBSH.int/dietphysicalactivity/en; ultima consultazione 3/5/2012.

[11] OBSH. Global recommendations on physical activity for health. Geneva: OBSH; 2010. http://whqlibdoc.OBSH.int/publications/2010/97892415 99979_eng.pdf; ultima consultazione3/5/2012. Rapporti ISTISAN 12/1438

[12] Vandelanotte C, Sugiyama T, Gardiner P, Owen N. Associations of leisure-time internet and computeruse with overweight and obesity, physical activity and sedentary behaviors: cross-sectional study. J Med Internet Res 2009;11:28.

[13] Pearson N, Biddle SJ. Sedentary behavior and dietary intake in children, adolescents, and adults. A syste.atic review. Am J Prev Med 2011; 41:178-88.

[14] Dietz WH Jr, Gortmaker SL. Do we fatten our children at the television set? Obesity and televisionviewing in children and adolescents. Pediatrics 1985;75:807-12.

[15] Erik Landhuis C, Poulton R, Welch D, Hancox RJ. Programming obesity and poor fitness: the long-term impact of childhood television. Obesity 2008;16:14579.

[16] Johnson-Taylor WL, Everhart JE. Modifiable environmental and behavioral determinants of overweight among children and adolescents: report of a workshop. Obesity 2006;14:929-66. 
[17] Lang T, Rayner G. Overcoming policy cacophony on obesity: an ecological public health framework for policymakers. Obes Rev 2007; 8:165-81.

[18] Ogden CL, Carroll MD, Kit BK, Flegal KM. Prevalence of obesity and trends in body mass index among US children and adolescents, 1999-2010. JAMA. 2012;307:483-90.

[19] Centers for Disease Control and Prevention. NCHS Health EStat: Prevalence of Obesity Among Children and Adolescents: United States, Trends 1963-1965 Through 2007-2008. 2010. Accessed March 2, 2012.

[20] Public Health Agency of Canada. Obesity in Canada: A Joint Report from the Public Health Agency of Canada and the Canadian Institute for Health Information; 2011:12-6.

[21] De Onis M, Blossner M, Borghi E. Global prevalence and trends of overweight and obesity among preschool children. Am J Clin Nutr. 2010;92:1257-64

[22] United Nations. Childinfo.org: Statistics by area / child nutrition / undernutrition / progress. 2012. Accessed March 6, 2012.

[23] Lien N, Henriksen HB, Nymoen LL, Wind M, Klepp KI. Availability of data assessing the prevalence and trends of overweight and obesity among European adolescents. Public Health Nutr. 2010;13:1680-7.

[24] Cattaneo A, Monasta L, Stamatakis E, et al. Overweight and obesity in infants and pre-school children in the European Union: a review of existing data. Obes Rev. 2010;11:389-98.

[25] World Health Organization / Europe. European Childhood Obesity Surveillance Initiative (COSI). 2010. Accessed March 6, 2012.

[26] OBSH Childhood Obesity Surveillance Initiative Dr. João Breda, OBSH - Regional Office for Europe http://ec.europa.eu/health/nutrition_physical_activity/do cs/ ev20120209_co03_en.pdf

[27] "National Prevalence of Obesity in a representative group population of school children living in Albania" M E D I C U S ISSN 1409-6366 UDC 61 Vol · XII (2) · Dhjetor 2009, 64-72.

[28] Institute of Statistics, Institute of Public Health [Albania] and ICF Macro. 2010. Albania Demographic and Health Survey 2008-09. Tirana, Albania: Institute of Statistics, Institute of Public Health and ICF Macro. http://www.measuredhs.com/ pubs/pdf/FR230/FR230.pdf.

[29] World Health Organization. Population-based prevention strategies for childhood obesity: report of a OBSH forum and technical meeting, Geneva, 15-17 December 2009. Geneva: World Health Organization; 2010.

[30] Nicklas TA, O’Neil CE, Berenson GS. Nutrient contribution of breakfast, secular trends, and the role of ready-to-eat-cereals: a review of data from the Bogalusa Heart Study. Am J Clin Nutr 1998;67:757-63.

[31] McPherson, R.S, Montgomery, D.H. and Nichaman, M.Z.(1995) Nutritional status of children; what do we know? Journal of Nutrition Education, 27: 225-234. 